\title{
ANALISIS PENGARUH KURS, SERTIFIKAT BANK INDONESIA DAN INFLASI TERHADAP KINERJA REKSADANA PENDAPATAN TETAP TAHUN 2015-2019
}

\author{
Andini Nurwulandari \\ Universitas Nasional, Jakarta \\ Email: andinmanajemen@gmail.com
}

\begin{abstract}
Abstrak
Setiap jenis investasi memiliki risiko yang berbeda. Namun, aturan umumnya adalah semakin tinggi kemungkinan pengembalian investasi semakin besar potensi risiko instrumen. Penelitian ini menggunakan metode kualitatif dengan pendekatan analisis deskriptif.. Sumber data adalah data sekunder dari situs resmi BI. OJK dan BPS. Riset ini mencakup seluruh reksadana OJK antara tahun 2015-2019. Pengambilan sampel dilakukan secara purposif. Dokumentasi data digunakan sebagai dalam pengambilan sampel. Hasil penelitian menemukan bahwa tingkat perkembangan berpengaruh negatif terhadap hasil reksadana pendapatan tetap, emakin rendah SBI maka output reksadana yang memiliki pendapatan tetap akan semakin buruk; dan inflasi tidak mempengaruhi efisiensi FIM, karena inflasi menunjukkan peningkatan biaya yang terus menerus untuk produk dan jasa.
\end{abstract}

Kata Kunci: Kurs, SBI, Inflasi, Kinerja, Pendapatan tetap, Reksadana.

\section{Abstract}

Each type of investment has different risks. However, the general rule is that the higher the likelihood of an investment the greater the risk of the instrument. This study uses a qualitative method with a descriptive analysis approach. The data source is secondary data from the official BI website. OJK and BPS. This research covers all OJK mutual funds between 20152019. Sampling was done purposively. Data documentation is used for sampling. The results of the study found that the level of development has a negative effect on the results of fixedincome mutual funds, the lower the SBI, the worse the output of mutual funds that have fixed income will be; and inflation does not affect the FIM, because inflation represents a continuous increase in costs for products and services.

Keywords: Exchange Rate, SBI, Inflation, Performance, Fixed Income, Mutual Funds.

\section{A. PENDAHULUAN}

Pasar saham memainkan peran penting bagi perekonomian suatu negara, karena modal menjalankan dua fungsi: pertama, menyediakan dana dari investor kepada perusahaan atau sebagai cara berbisnis (Juliyati, 2015). Dana kampanye dapat digunakan untuk menciptakan modal kerja, pertumbuhan. Industri dan sebagainya. Semuanya merupakan cara pengembangan instrumen keuangan bagi masyarakat, seperti reksadana dan unduhan kepemilikan saham dan instrumen lainnya (Permata \& Ghoni, 2019).

Oleh karena itu, masyarakat harus mengalokasikan manfaat dan biaya dari setiap instrumen sesuai dananya (Hasanudin. Nurwulandari. Adnyana \& Loviana. 2020). Tidak tersedianya tabungan dan investasi bagi perusahaan yang menguntungkan merupakan salah satu faktor penghambat pertumbuhan ekonomi di negara berkembang (Melati \& 
Nurwulandari, 2019). Tetapi di sisi lain, banyak negara berkembang memiliki tabungan yang signifikan dalam investasi komoditas, tetapi tidak didukung oleh kerangka keuangan yang sesuai untuk tabungan perusahaan manufaktur. Pilihan pendanaan investasi terdiri dari penentuan sumber dana yang akan digunakan (Kurniawati \& Silvi. 2009). Investasi digambarkan sebagai suatu kegiatan dimana dana ditetapkan untuk memperoleh pendapatan dan / atau meningkatkan nilai investasi (Agustin \& Mawardi. 2014). Investasi kini menjadi pengorbanan modal dalam potensi Investasi (Adnyana \& Nurwulandari. 2020). Investasi adalah dua investasi dalam satu atau lebih properti dan biasanya berjangka panjang dengan keuntungan yang diharapkan di masa depan (Nurwulandari \& Darwin. 2020).

Setiap alat investasi memiliki potensi risiko yang beragam (Nuryana. 2014). Namun prinsip yang diterapkan adalah bahwa semakin besar potensi pengembalian investasi, semakin besar pula potensi risiko suatu instrumen (Achyar. 2018). Demikian juga dengn pasar saham, risiko investasi ekuitas dapat dibedakan menjadi dua yaitu risiko non-sistematis dan risiko sistemik (Nugroho \& Sukhemi, 2015). Faktor mikro berkontribusi pada risiko nonsistematis. Risiko ini dapat dibatasi dengan memilih aset dan diversifikasi secara hati-hati karena terkait dengan lingkungan mikro bisnis (Absari, 2012). Misalnya risiko perusahaan termasuk ukuran utang (bahaya keuangan) dan sifat bisnis (risiko bisnis). Risiko industri merupakan bahaya karena adanya industri yang dituntut oleh organisasi. Sedangkan situasi makro suatu negara berkaitan dengan bahaya sistematis. Jika kinerja ekonomi suatu negara dalam kondisi yang buruk maka tidak akan efektif (Satoto, 2009). Kondisi makro suatu negara yang tersebar sangat mempengaruhi investasi saham. Salah satunya adalah kemungkinan inflasi menyebabkan penurunan daya beli. Nilai moneter tidak pernah stabil dalam perekonomian dunia. Di sisi lain, harga komoditas dan jasa tampaknya naik. Hal ini akan menurunkan daya beli mata uang tersebut sehingga menyebabkan inflasi (Kewal, 2012). Jika tingkat inflasi meningkat maka perekonomian mengalami penurunan sehingga dapat mempengaruhi penurunan laba suatu usaha yang mengakibatkan berkurangnya daya saing dalam pergerakan harga saham (sekuritas ekuitas).

Reksadana merupakan investasi tambahan pada aset keuangan publik, selain investasi pada deposito persediaan dan obligasi (Sedyaningrum \& Nuzula, 2016). Reksadana ada karena pada umumnya investor sulit untuk berinvestasi pada portofolio efeknya sendiri (Sari \& Purwanto, 2012). Kesulitan investor antara lain perlunya banyak analisis sekuritas dan pemantauan terus menerus terhadap kondisi pasar yang sangat intensif waktu (Panjaitan. 2012). Kebutuhan investasi saham yang relatif tinggi merupakan tantangan lain. Dua kelompok. Manajer Investasi dan BI bertanggung jawab atas .reksadana (Permata \& Ghoni. 2019). Manajer investasi adalah perusahaan investasi yang mengoperasikan portofolio produk sekuritas dan bertanggung jawab atas operasi investasi, termasuk peninjauan dan pemilihan bentuk investasi, pengambilan keputusan, pelacakan pasar, dan intervensi bunga. Ini adalah kliennya (Nurlita, 2015). Output reksadana dihitung dengan cara investor menangani portofolio ekuitas dana investor (Adhianto, 2020). Reksadana memberikan potensi keuntungan jangka panjang dibandingkan waktu dan tabungan (Salam. Widad \& Andriana. 2008).

Namun harus disadari bahwa semua investasi pada dasarnya berisiko. Investasi tersebut berbeda-beda tergantung pada jenis reksadana yang akan dipilih dari yang terendah hingga setinggi mungkin manfaat dan risiko dari masing-masing reksadana (Widjaja \& 


\section{ARTIKEL}

Mahayuni, 2009). Indonesia memiliki reksadana bersama termasuk .reksadana kreditur reksadana pendapatan bersama reksadana campuran reksadana di pasar moneter dan reksadana syariah. Setiap .reksadana memiliki karakteristik yang berbeda-beda. Reksadana saham tampaknya berisiko lebih besar daripada .reksadana pendapatan umum karna reksadana adalah anggota portofolio terpenting dalam saham dan tujuannya adalah untuk meningkatkan kepemilikan mereka. Variasi sifatnya ini menyebabkan perbedaan kinerja dalam .reksadana (Svensson, 2000). Kinerja setiap reksadana perlu dicermati secara cermat dan benchmark yang tepat digunakan karena karakteristik yang berbeda-beda tersebut.

Nilai tukar dapat ditentukan sesuai dengan uang untuk yang lain sebagai biaya dari satu norma moneter. Pengeluaran satu unit mata uang eksternal untuk mata uang dalam negeri adalah nilai tukar rata-rata. Ini karena ini paling banyak digunakan dalam analisis nilai tukar. Hal ini menunjukkan bahwa kenaikan harga mata uang atau harga legal tender internasional berarti depresiasi dan sebaliknya jika nilai tukar turun terhadap legal tender negara asal. Ketiga teori inflasi umumnya menunjukkan satu ciri khusus dari proses inflasi bukan teori inflasi yang masing-masing terdiri dari semua elemen dasar kenaikan harga. Ketiga teori tersebut adalah teori kuantitas teori utama dan teori struktur (Bastian \& Setterfield, 2020).

Hanya ada dua bentuk mata uang di antara banyakalat tukar. yaitu mata uang keras dan mata uang lunak. Empat elemen yaitu depresiasi. apresiasi. devaluasi. revaluasi. dapat menyebabkan perubahan nilai tukar (Hooper \& Sufi, 2020). Masalah di luar batas negara menjadi lebih kompleks. Dan secara umum. perdagangan antar negara dapat terjadi jika mekanisme pertukaran mata uang terjadi antar negara. Mata uang internasional mengacu pada mata uang asing nyata atau saat ini. termasuk deposito bank atau tagihan yang ditukar. Ukuran moneter yang signifikan adalah nilai tukar. karena perubahan nilai tukar dapat mempengaruhi kebijakan fiskal dengan mempengaruhi tekanan uang. Fluktuasi nilai tukar dapat mempengaruhi kebijakan keuangan dengan mempengaruhi pasar saham nasional juga.

\section{B. METODE}

Penelitian ini bersifat kuantitatif dan pendekatan deskriptif analitis. Data sekunder dari situs resmi BI. OJK dan BPS digunakan sebagai sumber data. Seluruh reksadana periode 2015-2019 telah didaftarkan di OJK dalam laporan ini. Alat untuk mengumpulkan sampel adalah pengambilan sampel yang ditargetkan. Pendekatan yang digunakan dalam analisis ini adalah dokumentasi data. Metodologi pengujian adalah uji asumsi standar dan model uji kelayakan adalah uji $\mathrm{F}$ dan koefisien keputusan berdasarkan aplikasi Eview 9.

\section{HASIL DAN PEMBAHASAN}

\section{Uji Multikolinearitas}

Uji multikolinearitas digunakan untuk mengetahui apakah model regresi ditemukan adanya korelasi antar variabel independen jika centered VIF dibawah 10 maka diduga tidak terjadi multikolinearitas dalam variabel regresi tersebut dan jika centered VIF diatas 10 maka diduga terjadi heterokedastisitas. Setelah data diolah dengan menggunakan aplikasi EViews 9 maka terlihat sebagai berikut hasilnya. 
ARTIKEL

Tabel 1 Multikolinearitas

\begin{tabular}{llll}
\hline \hline & \multicolumn{2}{l}{ Coefficient } & \multicolumn{2}{l}{ Uncentered Centered } \\
Variable & Variance & VIF & VIF \\
\hline \hline KURS & $2.51 \mathrm{E}-06$ & 102.9318 & 2.546873 \\
SBI & 4.429028 & 678.4678 & 4.835049 \\
INFLASI & 0.196823 & 25.02705 & 1.683427 \\
C & 0.588495 & 20832.43 & NA \\
\hline \hline
\end{tabular}

Sumber: Hasil olah data EViews 9

Tabel 1 di atas menunjukkan bahwa nilai centered VIF berada di bawah 10 . Berdasarkan tabel tersebut dapat disimpulkan bahwa model tersebut tidak terjadi multikolinearitas.

\section{Uji Auto Kolerasi}

Uji autokorelasi untuk menguji apakah dalam model regresi terdapat korelasi antara pengganggu periode $t$ dengan kesalahan pengganggu pada periode $t$ sebelumnya. Jika terjadi korelasi maka dinamakan ada masalah autokorelasi. Uji autokorelasi yang digunakan dalam penelitian ini adalah uji durbin Watson. Uji ini akan menghasilkan nilai DW-Stat yang akan menentukan ada tidaknya autokorelasi dalam model regresi pada batas-batas tertentu. Tabel 2 di bawah ini menunjukkan pengaruh uji multikolinearitas:

Tabel 2 Uji Autokorelasi

Breusch-Godfrey Serial Correlation LM Test:

\begin{tabular}{llll}
\hline \hline F-statistic & 0.210078 & Prob. F(2.53) & 0.8112 \\
Obs*R-squared & 0.471907 & Prob. Chi-Square(2) & 0.7898 \\
\hline \hline
\end{tabular}

Test Equation:

Dependent Variable: RESID

Method: Least Squares

Date: 01/22/20 Time: 22:22

Sample: 2011M01 2015M12

Included observations: 60

Presample missing value lagged residuals set to zero.

\begin{tabular}{lllll}
\hline \hline Variable & \multicolumn{2}{l}{ Coefficient Std. Error } & t-Statistic & Prob. \\
\hline \hline KURS & 0.000239 & 0.006002 & 0.045614 & 0.9738 \\
SBI & -0.07670 & 2.139771 & -0.008834 & 0.9940 \\
INFLASI & -0.05693 & 0.453868 & -0.113249 & 0.9104 \\
UKURAN & -0.00728 & 0.209350 & -0.034447 & 0.9828 \\
C & 0.027698 & 0.773037 & 0.0332067 & 0.9745 \\
RESID(-1) & -0.09596 & 0.140606 & -0.646927 & 0.5206 \\
RESID(-2) & -0.01859 & 0.141933 & -0.117765 & 0.9076 \\
\hline \hline R-squared & 0.007965 & Mean dependent var & $1.90 \mathrm{E}-16$ \\
Adjusted R-squared & -0.106652 & S.D. dependent var & 0.039309 \\
S.E. of regression & 0.041322 & Akaike info criterion & -3.426098
\end{tabular}




\section{ARTIKEL}

\begin{tabular}{llll} 
Sum squared resid & 0.090559 & Schwarz criterion & -3.181758 \\
Log likelihood & 109.7840 & Hannan-Quinn criter. & -3.330524 \\
F-statistic & 0.070036 & Durbin-Watson stat & 1.962704 \\
Prob(F-statistic) & 0.998661 & & \\
\hline \hline
\end{tabular}

Sumber: Olahan Data dari EViews 9

Data di atas menunjukan bahwa nilai DW yaitu $1.962704(1.5<$ DW-Stat $<2.5)$. maka model tersebut tidak mempunyai masalah korelasi.

\section{Uji Heterokedastisitas}

Uji heteroskedastisitas bertujuan untuk menguji apakah dalam model regresi linear terjadi ketidaksamaan varians dari residual satu pengamatan ke pengamatan yang lain. Jika tidak terjadi heteroskedastisitas. maka model regresi tersebut dinyatakan baik. Berikut ini adalah hasil dari uji heterokdasitas:

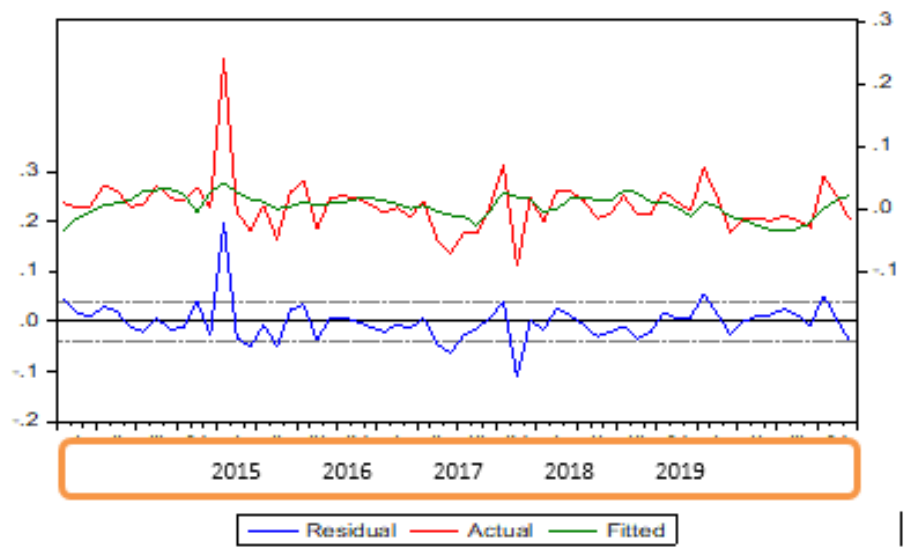

Sumber: Hasil Olah Data EViews 9

\section{Gambar 1 Uji Heterokedasitas}

Berdasarkan grafik pada gambar 1 tersebut maka diduga bahwa tidak terjadi heterokedastisitas karena residualnya tidak membentuk pola tertentu. Dengan kata lain, residualnya cenderung konstan. Untuk membuktikantidak adanya heterokedastisitas pada residual data maka dilakukan uji white heterocedasticity, yaitu dengan melihat nilai Obs*RSquared. Jika nilai $\mathrm{p}$ value Obs*R-Squared < 0.05 maka dapat dikatakan mengandung heterokedastisitas, jika $\mathrm{p}$ value Obs*R-Squared > 0.05 maka dapat dikatakan tidak mengandung heterokedastisitas

\section{Analisis Deskriptif}

Ringkasan data yang dikumpulkan dapat dilihat dalam variasi minimum, maksimum, mean, dan variabel studi memberikan gambaran atau kumpulan data. Temuan statistik dengan Eviews 9 adalah sebagai berikut.

Tabel 3 Statistik Deskriptif

\begin{tabular}{|c|c|c|c|c|}
\hline & RDPT & Kurs & SBI & Inflasi \\
\hline Rata-Rata & 0.003687 & 10.78204 & 0.065276 & 0.059862 \\
\hline Median & 0.004869 & 9.988600 & 0.067860 & 0.068000 \\
\hline Max & 0.248198 & 14.49700 & 0.076000 & 0.098900 \\
\hline Min & -0.082187 & 8.543000 & 0.058600 & 0.034600 \\
\hline
\end{tabular}


ARTIKEL

\begin{tabular}{|c|c|c|c|c|}
\hline Std. Dev. & 0.053387 & 1.766518 & 0.005698 & 0.025423 \\
\hline Skewness & 2.439305 & 0.392098 & -0.245000 & 0.250194 \\
\hline Kurtosis & 15.86526 & 1.784668 & 1.805870 & 1.838412 \\
\hline & & & & \\
\hline Jarque-Bera & 473.1650 & 5.305657 & 4.848157 & 4.003794 \\
\hline Probabilitas & 0.000000 & 0.085041 & 0.098670 & 0.145165 \\
\hline & & & & \\
\hline jumlah & 0.290688 & 647.2730 & 3.820600 & 3.541200 \\
\hline Sum Sq. Dev. & 0.120609 & 182.9483 & 0.002852 & 0.015044 \\
\hline & & & & \\
\hline Observasi & 60.00 & 60.00 & 60.00 & 60.00 \\
\hline
\end{tabular}

Sumber: Data diolah dari Eviews 9

Hasil review deskriptif pada Tabel 3 menunjukkan bahwa penelitian ini memiliki 60 observasi. Selama lima tahun, data dalam analisis ini telah digunakan setiap bulan. Oleh karena itu hingga 60 observasi diterima. Nilai rata-rata membagi total nilai dari jumlah data yang digunakan.

Mean dari NAB Reksadana Pendapatan Tetap bulanan selama periode lima tahun adalah sebesar 0.003687 mengindikasikan bahwa rata-rata sampel mengalami perubahan NAB sebesar 0.003687 poin per bulan. Nilai maksimum dan minimum dari variabel ini adalah 0.248198 dan -0.248198 . Variabel ini memiliki penyebaran data sebesar 0.053387 nilai ini terlihat dari standar deviasi variabel.

Selanjutnya adalah besarnya nilai rata-rata (mean) dari Kurs sebesar 10.782.04 menjelaskan bahwa rata-rata sampel mengalami perubahan Kurs sebesar 10.782.04 rupiah per bulan. Nilai maksimum dan minimum dari variabel ini adalah 14.49700 dan 8.543.000. Variabel ini memiliki penyebaran data sebesar 1.766518 terlihat dari standar deviasi.

Sertifikat Bank Indonnesia (SBI) memiliki rata-rata 0.065276 yang mengartikan bahwa rata-rata sampel mengalami perubahan SBI sebesar 0.065276 poin per bulan. Nilai maksimum dan minimum dari variabel ini adalah 0.076000 dan 0.058600 . Variabel ini memiliki penyebaran data sebessar 0.005698 .

Inflasi memiliki rata-rata 0.059862 mengalami perubahan Inflasi sebesar 0.059862 poin per bulan. nilai maksimum dan minimum dari variabel ini adalah 0.098900 dan 0.034600 . Variabel ini memiliki penyebaran data sebesar 0.025423 .

\section{Analisis Regresi Linier Berganda}

Hasil analisis regresi linier berganda dapat dilihat pada tabel 4 berikut ini:

\section{Tabel 4 Metode Least Square}

Dependent Variable: RDPT

Method: Least Squares

Date: 01/22/20 Time: 22:13

Sample: 2011M01 2015M12

Included observations: 60

\begin{tabular}{|c|c|c|c|}
\hline Variable & CoefficientStd. Error & $\mathrm{t}$-Statistic & Prob. \\
\hline KURS & -0.0128440 .004922 & -2.411588 & 0.0193 \\
\hline SBI & 5.9878692 .106904 & 2.842025 & 0.0064 \\
\hline
\end{tabular}


ARTIKEL

\begin{tabular}{lllll} 
INFLASI & -0.761388 & 0.432366 & -1.761080 & 0.0848 \\
C & -1.769520 & 0.760533 & -2.326705 & 0.0238 \\
\hline \hline R-squared & 0.175028 & Mean dependent var & 0.004679 \\
Adjusted R-squared & 0.115028 & S.D. dependent var & 0.043279 \\
S.E. of regression & 0.040714 & Akaike info criterion & -3.484877 \\
Sum squared resid & 0.091167 & Schwarz criterion & -3.310350 \\
Log likelihood & 109.5462 & Hannan-Quinn criter. & -3.416602 \\
F-statistic & 2.917205 & Durbin-Watson stat & 2.133082 \\
Prob(F-statistic) & 0.029277 & & \\
\hline \hline
\end{tabular}

Ule Sumber: Hasil Olah Data EViews 9

Berdasarkan running data tersebut maka moderl regresi linier berganda dapat dinyatakan dalam persamaan koefisien sebagai berikut: KRDPT $=-1.769510$ bahwa konstanta regresi sebesar -1.769520 . Hal ini artinya apabila nilai kurs. SBI, dan inflasi konstan maka nilai kinerja reksadana pendapatan tetap sebesar -1.769520. Dapat dilihat berdasarkan hasil estimasi. Kurs memiliki koefisien sebesar -0.011844 dengan probabilitas $0.0193<0.05$ maka hal ini dapat menjelaskan bahwa kurs negatif dan signifikan terhadap Kinerja Reksadana Pendapatan Tetap. Dengan demikian dapat diartikan jika kurs naik satu poin maka kinerja reksadana pendapatan tetap turun sebesar 0.011844 .

Sedangkan untuk Sertifikat Bank Indonesia (SBI) memiliki koefisien sebesar 5.987869 dengan probabilitas sebesar $0.0064<0.05$ maka hal ini menjelaskan bahwa SBI berpengaruh positif dan signifikan terhadap Kinerja Reksadana Pendapatan Tetap. Dengan demikian dapat diartikan jika SBI naik satu poin maka kinerja Reksadana Pendapatan Tetap naik sebesar 5.987869 .

Untuk variabel Inflasi memiliki koefisien sebesar -0.761388 dengan probabilitas $0.0848>0.05$ maka hal ini menjelaskan bahwa inflasi negatif tidak berpengaruh signifikan terhadap Kinerja Reksadana Pendapatan Tetap. Dengan demikian jika inflasi naik satu maka kinerja reksadana pendapatan teap turun sebesar 0.761388 .

\section{Uji Kelayakan Model (Uji F)}

Uji F (F-Test) atau uji kelayakan model dimaksudkan untuk mengetahui apakah model dalam penelitian ini layak untuk diteliti. Uji F pada dasarnya menunjukkan apakah semua variabel bebas dalam model mempunyai pengaruh secara simultan terhadap variabel terikat. Nilai F-counter sebesar 2.917205 berdasarkan tabel 4 di atas dengan tingkat signifikansi $0.029277<0.05$.

\section{Uji Koefisien Determinasi $\left(R^{2}\right)$}

Nilai R2 dimaksudkan untuk mendeteksi persentase variabel respon independen dijelaskan. Nilai R2 atau R square sebesar 0.175028 atau $17.35 \%$ dari tabel berikut. Ini menunjukkan bahwa ada empat variabel berbeda dalam mata uang, bank sertifikat Indonesia, inflasi serta ukuran reksadana. yang menjelaskan kemungkinan terjadinya fluktuasi $17.35 \%$ pada reksadana, sedangkan sisanya $81.65 \%$ ditentukan oleh faktor-faktor yang menyebabkan reksadana mengalami fluktuasi sebesar $17.35 \%$. maka belum teridentifikasi. 


\section{ARTIKEL}

\section{Pengaruh Kurs Terhadap Kinerja Reksadana Pendapatan Tetap}

Mata uang tersebut memiliki nilai koefisien -0.012844. Hal ini menunjukkan bahwa reksadana pendapatan tetap antar bursa berdampak negatif terhadap kinerja. Nilai tukar dikatakan berpengaruh negatif dan penting terhadap output reksadana pendapatan tetap dengan angka $0.0193>0.05$.

Hal tersebut terkait dengan suku bunga yang melebihi nilai kupon harian, sehingga investor mentransfer dananya yang disimpan pada dana penghimpunan pendapatan tetap ke atau lebih tepatnya deposito ke sektor perbankan. Jika dana dari reksadana pendapatan terus menerus ditarik atau diganti, outputnya akan menurun dan sebaliknya. Investor akan meneruskan dananya ke dana resiprokal pendapatan tetap jika suku bunga 10 rendah dan di bawah nilai kupon yang ditetapkan dalam penarikan, sehingga output dana resiprokal pendapatan tetap akan meningkat.

\section{Pengaruh SBI Terhadap Kinerja Reksadana Pendapatan Tetap}

SBI memiliki nilai koefisien 5.987969. Hal ini menunjukkan bahwa SBI berdampak positif terhadap kinerja reksadana untuk pendapatan tetap. Dengan nilai probabilitas $0.0064<$ 0.05. pengaruh positif dan signifikan SBI terhadap hasil analisis menunjukkan bahwa kenaikan SBI akan berdampak pada output SBI. Namun, output dana resiprokal pendapatan tetap diperkirakan akan menurun jika SBI menurun. SBI digunakan untuk menghitung tingkat pengembalian sebagai suku bunga acuan bagi lembaga keuangan termasuk dana timbal balik.

\section{Pengaruh Inflasi Terhadap Kinerja Reksadana Pendapatan Tetap}

Nilai inflasi bernilai negatif. yaitu -0.761388. Hal ini menunjukkan bahwa dampak terhadap output reksadana pendapatan tetap timbal balik antar inflasi bersifat merugikan. Dengan nilai probabilitas 0.0848> 0.05 maka dampak inflasi terhadap output reksadana pendapatan tetap dapat dikatakan negatif dan tidak signifikan. Dengan demikian, output reksadana pendapatan tetap tidak terpengaruh oleh inflasi. Dari hasil laporan ini, tidak ada dampak inflasi terhadap output reksadana pendapatan tetap. Artinya, besaran inflasi yang dijaga FIF tidak berpengaruh terhadap penyesuaian output pendapatan tetap dan inflasi tidak dapat dijadikan pedoman bagi investor dalam pengembangan FIF.

\section{KESIMPULAN}

Tingkat perkembangan mempunyai pengaruh negatif terhadap hasil reksadana pendapatan tetap, hal ini menjelaskan mengapa output reksadana menurun jika valuasinya meningkat. Memang, output dana pendapatan tetap akan meningkat jika nilai tukar turun. Akibatnya, dalam jangka panjang kenaikan suku bunga, penurunan nilai aset bersih FIM menyebabkan mayoritas masyarakat atau investor mengalihkan asetnya dari reksadana ke instrumen lain (perbankan atau deposito) karena adanya fakta tersebut. Bahwa sebagian besar investor menggunakan return mereka sebagai alat ukur investasi. Reksadana pendapatan tetap mengandung 80 persen pendapatan tetap. Semakin tinggi suku bunga SBI, semakin baik output reksadana pendapatan tetap. Semakin rendah SBI maka output dari reksadana yang memiliki pendapatan tetap semakin memburuk. Ini karena populasi akan menurun seiring dengan kenaikan suku bunga pasar, dan ini menghasilkan pengembalian yang lebih tinggi. Penundaan akan meningkat dan imbal hasil akan menurun jika minat konsumen turun. SBI 
diterapkan untuk menentukan tingkat imbal hasil obligasi. Selain itu, inflasi tidak mempengaruhi efisiensi FIM. Skala inflasi memiliki pengaruh yang kecil terhadap pergeseran output dalam dana timbal balik pendapatan tetap. Oleh karena itu, inflasi tidak dapat digunakan untuk diterapkan pada investor karena meningkatkan dana timbal balik pendapatan tetap. Investor juga akan memilih modalnya untuk memenuhi kebutuhan mereka atau investasi dalam reksadana pendapatan tetap timbal balik, karena inflasi menunjukkan kenaikan biaya yang berkelanjutan untuk produk dan layanan.

\section{DAFTAR PUSTAKA}

Absari, D. U. A., Sudarma. M., \& Chandrarin. G. (2012). Analisis Pengaruh Faktor Fundamental Perusahaan Dan Risiko Sistematis Terhadap Return Saham. El Muhasaba: Jurnal Akuntansi (e-journal), 3(2).

Achyar, M. (2018). Sukuk: Instrumen Pembiayaan Islami Potensial. Jurnal Labatila. 2(01). $1-25$.

Adhianto, D. (2020). Investasi .reksadana Sebagai Alternatif Investasi Bagi Investor Pemula. Jurnal E-Bis (Ekonomi-Bisnis). 4(1). 32-44.

Adnyana, I., \& Nurwulandari, A. (2020). Empirical Examination of Intersectoral Linkages Between Tourism and Regional Economy by Using the Social Accounting Matrix. International Journal of Economics \& Business Administration (IJEBA). 8(1). 425-432.

Agustin, P., \& Mawardi, I. (2014). Perilaku Investor Muslim dalam Bertransaksi Saham di Pasar Modal. Jurnal Ekonomi Syariah Teori dan Terapan. 1(12).

Bastian, E. F., \& Setterfield, M. (2020). Nominal exchange rate shocks and inflation in an open economy: towards a structuralist inflation targeting agenda. Cambridge Journal of Economics. 44(6). 1271-1299.

Hasanudin, H., Nurwulandari, A., Adnyana, I. M., \& Loviana. N. (2020). The Effect of Ownership and Financial Performance on Firm Value of Oil and Gas Mining Companies in Indonesia. International Journal of Energy Economics and Policy. 10(5). 103.

Hooper, P., Mishkin, F. S., \& Sufi, A. (2020). Prospects for inflation in a high pressure economy: Is the Phillips curve dead or is it just hibernating?. Research in Economics. 74(1). 26-62.

Juliati, Y. S. (2015). Peranan Pasar Modal Dalam Perekonomian Negara. Human Falah: Jurnal Ekonomi dan Bisnis Islam. 2(1). 95-112.

Melati, M., \& Nurwulandari, A. (2019). Analisis Reaksi Pasar terhadap Stock Split pada Perusahaan Bertumbuh dan Tidak Bertumbuh. Oikonomia: Jurnal Manajemen. 13(2).

Nugroho, I., \& Sukhemi, S. (2015). Pengaruh Risiko Sistematis dan Likuiditas terhadap Return Saham pada Perusahaan Manufaktur yang terdaftar di BEI. Jurnal Akuntansi. 3(2). 63-74.

Nurlita, A. (2015). Investasi di pasar modal syariah dalam kajian Islam. Kutubkhanah. 17(1). $1-20$.

Nurwulandari, A., \& Darwin, M. (2020). Heywood Case Data Statistik: Menggunakan Teknik Respesifikasi Model. Nucleus. 1(2). 74-84. 
Nuryana, F. (2014). Analisis Pemilihan Instrumen Investasi Bisnis Emas. Valuta Asing dan Saham. IQTISHADIA: Jurnal Ekonomi dan Perbankan Syariah. 1(2). 196-220.

Panjaitan, M. V. (2012). Analisis Kemampuan Stock Selection dan Market Timing Manajer Investasi Pada Reksadana Saham di Indonesia. Jurnal Ilmiah Mahasiswa Manajemen. 1(2).

Permata, C. P., \& Ghoni, M. A. (2019). Peranan Pasar Modal Dalam Perekonomian Negara Indonesia. Jurnal AkunStie (JAS). 5(2). 50-61.

Purnamasari, L., Kurniawati, S. L., \& Silvi, M. (2009). Interdependensi Antara Keputusan Investasi. Keputusan Pendanaan dan Keputusan Dividen. Jurnal Keuangan dan Perbankan. 13(1). 106-119.

Salam, M., Widad, A., \& Andriana, I. (2008). Penilaian Kinerja .reksadana Terbuka Pada Pt. Trimegah Securities Tbk Tahun 2006 Dengan Metode Jensen (Doctoral dissertation. Sriwijaya University).

Sari, A. P. N., \& Purwanto, A. (2012). Analisis Kebijakan Alokasi Aset. Kinerja Manajer Investasi dan Tingkat Risiko terhadap Kinerja Reksadana Saham di Indonesia (Doctoral dissertation. Fakultas Ekonomika dan Bisnis).

Satoto, S. H. (2009). Strategi diversifikasi terhadap kinerja perusahaan. Jurnal Keuangan dan Perbankan. 13(2). 280-287.

Sedyaningrum, M., \& Nuzula, N. F. (2016). Pengaruh Jumlah Nilai Ekspor. Impor Dan Pertumbuhan Ekonomi Terhadap Nilai Tukar Dan Daya Beli Masyarakat Di Indonesia Studi Pada Bank Indonesia Periode Tahun 2006: iv-2015: iii. Jurnal Administrasi Bisnis. 34(1). 114-121.

Svensson, L. E. (2000). Open-economy inflation targeting. Journal of international economics. 50(1). 155-183.

Widjaja, I., \& Mahayuni, M. W. (2009). Analisis Kinerja Reksadana Fixed Income dan Hubungannya dengan Umur Reksadana. Jurnal Organisasi dan Manajemen. Tahun. 11(01). 122-140. 